$1-1-1965$

\title{
Carcass composition and growth performance of swine as affected by restricted nutrient allowance
}

James Leonard McBee

G. C.Anderson

Dale Wendel Zinn

Follow this and additional works at: https://researchrepository.wvu.edu/ wv_agricultural_and_forestry_experiment_station_bulletins

\section{Digital Commons Citation}

McBee, James Leonard; Anderson, G. C.; and Zinn, Dale Wendel, "Carcass composition and growth performance of swine as affected by restricted nutrient allowance" (1965). West Virginia Agricultural and Forestry Experiment Station Bulletins. 513.

https://researchrepository.wvu.edu/wv_agricultural_and_forestry_experiment_station_bulletins/477 @ WVU. It has been accepted for inclusion in West Virginia Agricultural and Forestry Experiment Station Bulletins by an authorized administrator of The Research Repository @WVU. For more information, please contact ian.harmon@mail.wvu.edu. 
Digitized by the Internet Archive in 2010 with funding from

Lyrasis Members and Sloan Foundation 


\section{Carcass Composition and Growth Performance} of Swine as Affected by Restricted Nutrient Allowance

$$
\begin{aligned}
& \text { 16 Ing. Lfopery }
\end{aligned}
$$

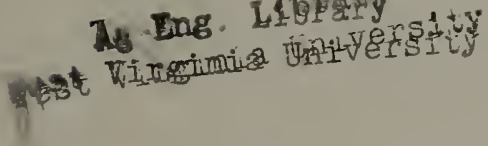

West Virginia University Agrieultural Experiment Station 


\title{
THE AUTHORS
}

James L. McBee, Jr. is Associate Animal Husbandman and G. C. Anderson is Animal Husbandman in the West Virginia University Agricultural Experiment Station. D. W. Zinn, at the time of this study, was a Research Assistant.

\author{
WEST ViRGINia UNIVERSITY \\ Agricultural Experiment Station \\ College of Agriculture, Forestry, and Home Economics \\ A. H. Vanlandingham, Drrector \\ Morgantown
}




\section{Carcass Composition and Growth Performance Of Swine as Affected by Restricted Nutrient Allowance}

\section{J. L. McBEE, JR., G. C. ANDERSON, AND D. W. ZINN}

The change in consumers' habits during the past two decades from diets high in fat to the present low-fat diets has become a very pressing problem for the pork producer. For the past several years the swine industry has been aware of the problems confronting it and has set about selecting and testing breeding herds in an effort to produce true meat-type hogs. In selecting for the meat-type hog the breeder needs a method by which he can determine the ratio of lean to fat in the body of live animals, thus eliminating the need for sacrificing potential herd improving stock to obtain carcass information. The method must be accurate, economical, and easy to use if it is to be employed to advantage.

Permanent improvement must be achieved through the application of genetic principles. However, certain methods of feeding and management are believed to favorably influence carcass leanness, and the use of these techniques could provide a temporary solution to the problem of carcass quality.

Certain environmental factors influence the development of an animal's body. McMeeken (1940) reported that growth during a particular period has a greater effect on the carcass composition than average growth over the whole feeding period. Muscle formation increases from birth up to 16 weeks of age and then declines, while fat deposition increases progressively up to market weight. McMeekan reported that if pigs are grown so slowly as to be stunted in early life, the weight gains are characteristically high in fat when the animals are placed on a high plane of nutrition. Conversely, lean tissue development is stimulated and the deposition of fat retarded if the pigs are maintained on a high plane of nutrition during the growing period and on a low plane during the finishing period.

The experiments described in this report were undertaken in 19551956 to study the effect of different levels of nutrition on carcass leanness when pigs were maintained on pasture or in dry lot. An accompanying study was made of some methods available for determining the ratio 
of lean to fat in the live animal's body. The principal objectives were (1) to study the effect of different levels of nutrition upon the rate and efficiency of gain, (2) to ascertain if these different nutritional regimes had any effect upon carcass composition, and (3) to evaluate different methods of measuring the body composition of live animals.

\section{EXPERIMENTAL PROCEDURE}

Purebred Duroc and Berkshire pigs from the University swine herd were fed and managed in accordance with standard husbandry practices until assigned to an experimental treatment.

In Trial I the pigs were moved to fertilized bluegrass-white clover pasture plots one week prior to the beginning of the experiment. Each lot provided approximately one acre of pasture with adequate shade. The lots were adjacent to each other, and after the feeding trial was initiated the animals were rotated bi-weekly to insure, as nearly as possible, similar pasture for the three experimental lots. Berkshire and Duroc pigs were used for Trial I. Animals of each breed were separated and divided into uniform groups on the basis of age, sex and parentage. Pigs in each group were then randomly assigned to lots. When each lot contained its complement of five Berkshires and five Durocs it was assigned a treatment at random.

Trial I was designed to study the effect of restricted feeding on the performance and carcass composition of pigs maintained on pasture. All experimental animals were hand fed ration No. 134 twice daily. The level of feeding of the full-fed lot was periodically adjusted to promote maximum consumption and to minimize feed wastage. The limited-fed lot received one-half the amount of feed consumed by the full-fed lot. A third lot was full fed to a live weight of approximately $125 \mathrm{lbs}$. and then received one-half of a full feed from $125 \mathrm{lbs}$. to market weight.

Trial II was conducted in a swine feeding shed containing $9 \times 24$ foot concrete-floored pens without outside exercise lots. All pens were bedded with wheat straw. In this trial animals of the Duroc breed were systematically assigned to the different treatments according ito the previously mentioned criteria. Each treatment was duplicated, and the groups were randomly assigned to location within the swine shed.

Trial II was designed to study the effect of limiting the total digestible nutrients (T.D.N.) of the ration on the carcass composition. This was accomplished by adding to the ration 37 per cent by weight of ground alfalfa hay. The addition of the alfalfa hay resulted in a reduction of the calculated T.D.N. from 73 per cent in the low-fiber ration to 58 per cent in the high-fiber ration, and an increase in the calculated 
crude fiber content from 4 to 12 per cent, respectively. Each ration was supplemented with equal amounts of mineral and vitamin mixtures. In this trial one lot received low-fiber ration No. 141 from 70 to 200 lbs.; a second lot was fed low-fiber ration No. 141 from 70 to $125 \mathrm{lbs}$. and high-fiber ration No. 140 from 125 to $200 \mathrm{lbs}$.; and a third lot received high-fiber ration No. 140 from 70 to $200 \mathrm{lbs}$. Each lot in Trial II had access to a standard self feeder which would accommodate six animals at any one time. In all trials the pigs in each lot had free access to an automatic waterer. Feed consumption records were kept on all groups.

The composition of the experimental rations is presented in Table 1 . Vitamins and minerals were added in sufficient quantities to equal or slightly exceed currently recommended levels.

The experimental pigs were weighed individually every two weeks; or more often when their weight approached 125, 165 and 200 lbs. Each trial was terminated when the average weight of all lots reached approximately $200 \mathrm{lbs}$.

In each trial, the back fat thickness was measured when the average weight of the pigs in each lot was 125, 165 and $200 \mathrm{lbs}$. Measurements were obtained by the probe method of Hazel and Kline (1952) and with a lean meter. In both cases the measurements were taken one and one-half inches off the mid-line just behind the shoulder, at the middle of the back, and at the middle of the loin as suggested by Hazel and Kline (1952). At the same time, the length of body was measured by determining the distance down the center of the. back from the poll to tail with a metal tape. When this measurement was taken an effort was made to hold the animal in a natural position to obtain as accurate data as possible but considerable variation was occasionally encountered.

The amount of body fat at the above mentioned weight periods was estimated by use of the antipyrine technique developed by Soberman et al. (1949), and modified by Zinn (1956), using the work of Kraybill et al. (1953) as a guide.

At the termination of the trials the experimental swine were slaughtered, chilled for 24 hours at $32^{\circ} \mathrm{F}$, and processed. The following carcass data were collected: dressing per cent, length of carcass, thickness of the subcutaneous fat, and weight of the closely trimmed skinned ham, shoulder, and loin. A tracing was made of the longissimus dorsi muscle of the loin at the fourteenth rib, from which the area in square inches was obtained by a planimeter reading.

Statistical Analysis. The data were analyzed statistically following methods of Snedecor (1946). The results obtained in Trials I and II were analyzed separately. The data obtained in Trial I resulted in 
unequal subclass numbers. Therefore, enough data were randomly discarded to make equal subclass numbers and permit a simple sum of squares analysis.

The correlations of average back fat thickness as measured by the lean meter and probe were analyzed by average within-lot correlations as suggested by Snedecor (1946). This same procedure was used to $\mathrm{d} r$ termine the correlation between the average tail to poll length and carcass length.

\section{RESULTS AND DISCUSSION}

Average Daily Gain and Feed Efficiency. Experimental data were collected for the live weight periods from weaning to $125 \mathrm{lbs}$., 125 to $165 \mathrm{lbs}$. and 165 to $200 \mathrm{lbs}$. Because of differences noted in the average daily gain and feed consumption for each of the periods, the results are given separately for the respective periods, and are presented in Tables 2 and 3.

Weaning to $125 \mathrm{lbs}$. Restricting the experimental animals to 50 per cent of a full feed of ration No. 134 while they were on pasture resulted in a highly significant decrease in the average daily gain. Although restricting the ration resulted in a 28 per cent decrease in rate of gain, feed efficiency was increased by 24 per cent.

In Trial II a reduction of the total digestible nutrients (T.D.N..) in the ration resulted in a highly significant decrease in the average daily gain. The pigs receiving high fiber ration No. 140 required 11 days longer to reach $125 \mathrm{lbs}$. This was accompanied by an increase of approximately 40 per cent in the feed required for $100 \mathrm{lbs}$. of gain.

Live weight period 125 to $165 \mathrm{lbs}$. Pigs in Trial I that received a full feed of ration No. 134 from weaning to $125 \mathrm{lbs}$., responded much the same when restricted to 50 per cent of a full feed at $125 \mathrm{lbs}$., as did the experimental pigs receiving 50 per cent of a full feed from weaning. The results show a highly significant decrease in the rate of gain with an increased feed efficiency for both lots. The pigs which were on a full feed prior to the reduction required a few days to become adjusted to the new feeding level. As a result their rate of gain was reduced more than expected.

In Trial II, increasing the fiber content of the ration at a live weight of $125 \mathrm{lbs}$. resulted in a 30 per cent decrease in rate of gain. On the other hand, the rate of gain made by pigs maintained on the high fiber ration from weaning was reduced by 20 per cent in one lot, while an increase of 20 per cent in rate of gain was recorded in another lot. An explanation for the increased rate of gain in the one lot cannot 
TABLE 1

Composition of Experimental Rations

Trials I and II

\begin{tabular}{lccc}
\hline \hline \multicolumn{1}{c}{ Ration Number } & 134 & 140 & 141 \\
\hline \multicolumn{1}{c}{ Description } & Trial I & $\begin{array}{c}\text { High-Fiber } \\
\text { Trial II }\end{array}$ & $\begin{array}{c}\text { Low-Fiber } \\
\text { Trial II }\end{array}$ \\
\hline Ground yellow corn & 72.0 & 45.0 & 71.0 \\
Soybean meal, solvent & 25.0 & 15.0 & 21.0 \\
Alfalfa meal' $^{\text {Mineral mixture }}{ }^{2}$ & - & 37.0 & 5.0 \\
Vitamins A and D $^{3}$ & 2.0 & 2.0 & 2.0 \\
B vitamin mixture & 0.5 & 0.5 & 0.5 \\
Total pounds & 1.0 & 1.0 & 1.0 \\
Calculated crude protein, (per cent) $^{4}----$ & 17.73 & 16.43 & 16.50 \\
Calculated crude fiber, (per cent) & 2.71 & 12.21 & 3.90 \\
Calculated T.D.N., (per cent) & 75.50 & 57.90 & 73.48 \\
\hline
\end{tabular}

'The alfalfa meal was finely ground, green, leafy alfalfa hay produced on the University Animal Husbandry Farm.

${ }_{2}^{2}$ The mineral supplement contained $100 \mathrm{lbs}$. steamed bone meal, $50 \mathrm{lbs}$. salt, $50 \mathrm{lbs}$. ground limestone, $400 \mathrm{~g}$. ferrous sulfate, $300 \mathrm{~g}$. manganese sulfate, $15 \mathrm{~g}$. copper sulfate, $30 \mathrm{~g}$. cobalt chloride, and $30 \mathrm{~g}$. potassium iodide.

${ }^{3}$ The vitamin $A$ and $D$ concentrate contained 4,000 International Units of vitamin A and 300 International Units of vitamin D per gram.

${ }^{4}$ The concentrated B vitamins were pre-mixed with cerelose and then incorporated in wheat shorts. This mixture was added to the experimental rations in sufficient quantities to supply the following amounts per pound of ration: $3.7 \mathrm{mg}$. riboflavin; $12.5 \mathrm{mg}$. niacin; $18.5 \mathrm{mg}$. calcium pantothenate and $9.0 \mathrm{mcg}$. $B_{12 .}$ Chicago.

The vitamin A and D concentrate was purchased from Dawes and Company,

The B vitamins used in this work were supplied by Merck and Company, Inc., Rahway, N. J.

be made from the experimental data although the chance assignment of two unusually aggressive pigs to this lot may be partly responsible.

Live weight period 165 to $200 \mathrm{lbs}$. In Trial I restricting feed intake resulted in a highly significant decrease in rate of gain. The restrictedfed lots required 15 and 16 days longer to reach a market weight of $200 \mathrm{lbs}$. This was accompanied by a decrease of 22 and 29 per cent respectively in feed efficiency.

On the other hand the rate of gain was not significantly altered when fiber was used to restrict T.D.N. intake in Trial II. This treatment slightly increased the time needed to attain a weight of $200 \mathrm{lbs}$. and improved feed efficiency by approximately 10 per cent. 


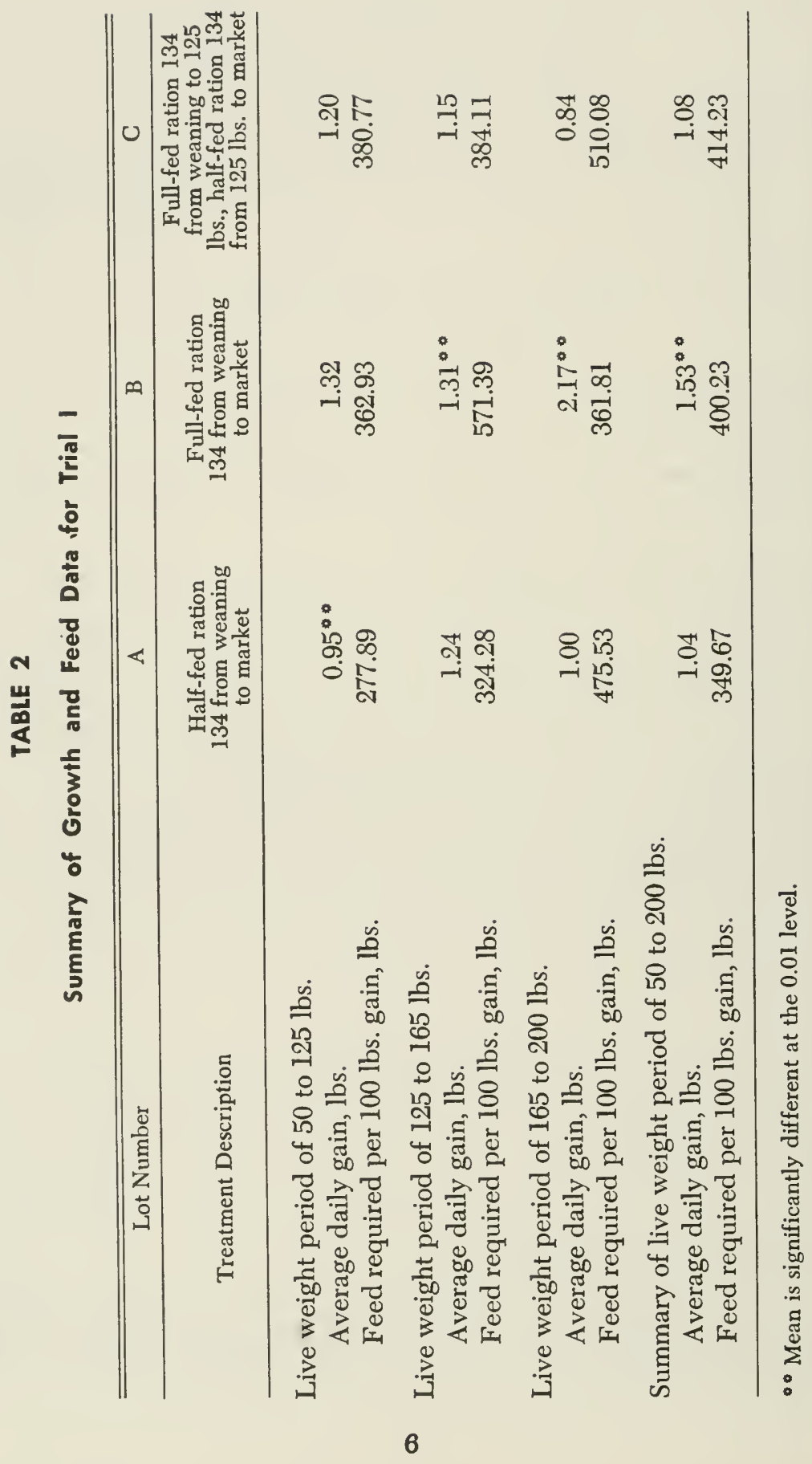




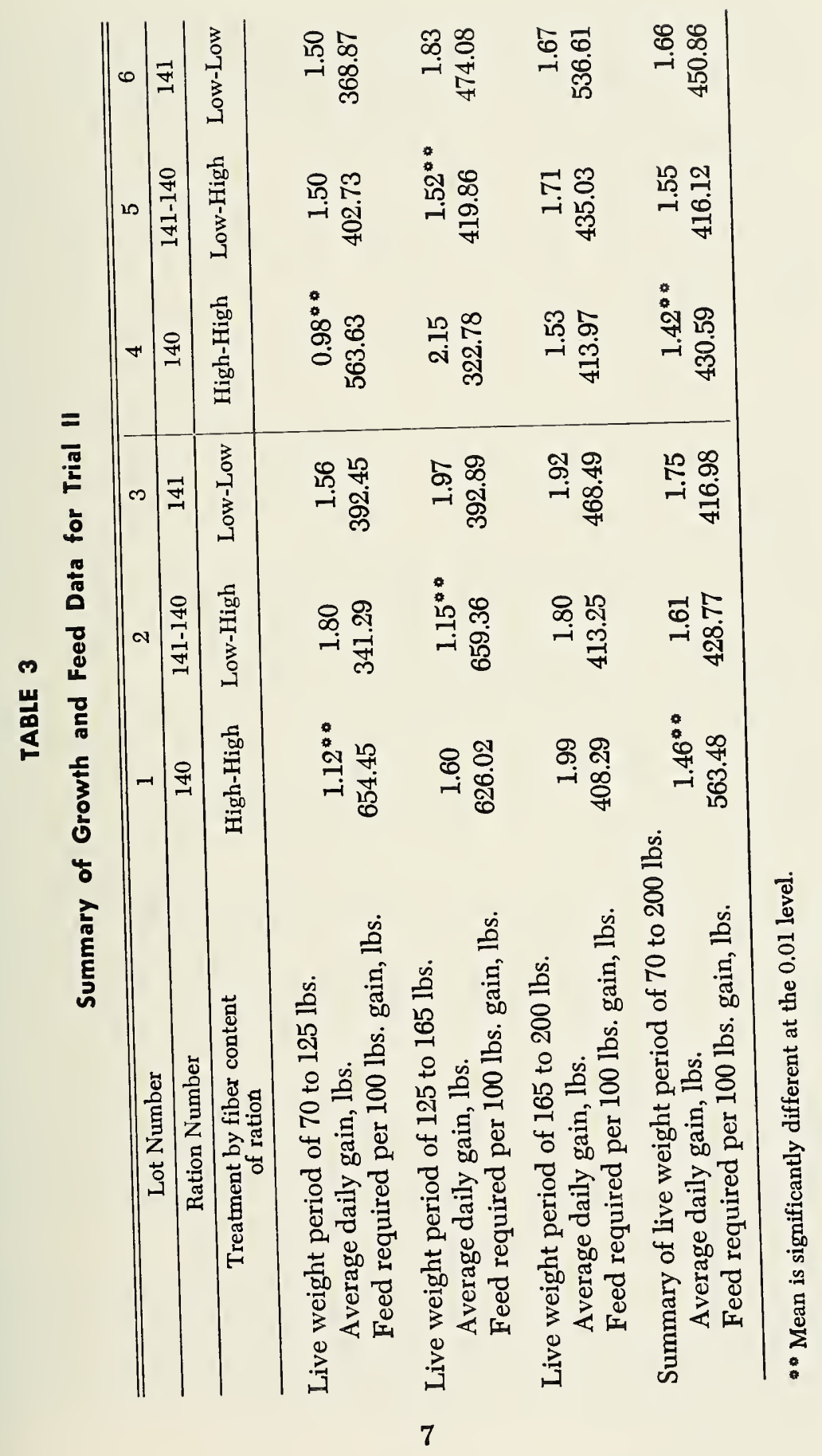


Live weight period weaning to $200 \mathrm{lbs}$. In Trial I the pigs fed 50 per cent of a full feed from weaning to market gained $0.49 \mathrm{lb}$. less per day than the full-fed pigs. Although the restricted-fed pigs required 44 days longer to reach a market weight of $200 \mathrm{lbs}$., they required 13 per cent less feed to produce a unit of gain.

Pigs receiving a full feed of ration No. 134 from weaning to $125 \mathrm{lbs}$. and thereafter fed 50 per cent of a full feed to $200 \mathrm{lbs}$., gained 0.45 lb. less per day than the full-fed pigs. Restricting feed intake during the fattening period resulted in an increase of 30 days to reach a market weight of 200 lbs. with a 3.4 per cent decrease in feed efficiency.

The results of Trial II show a highly significant difference in rate of gain attributed to treatment. Diluting the ration T.D.N. from 75 to 58 per cent with ground alfalfa resulted in a $0.26 \mathrm{lb}$. reduction in average daily gain for the entire experimental period. On the other hand, pigs receiving a ration containing 75 per cent T.D.N. to $125 \mathrm{lbs}$. and thereafter fed a ration containing 58 per cent T.D.N., showed a reduction of $0.12^{\circ} \mathrm{lb}$. in average daily gain. The pigs on the restricted T.D.N. intake from weaning to market required, on the average, an additional 25 days to reach market weight, while those on a restricted T.D.N. intake from 125 lbs. to market required an average of 9 days longer than their controls to reach the market weight of $200 \mathrm{lbs}$.

Effect of a Restricted Feed Allowance on Rate and Efficiency of Gain. Restricting the feed intake of growing-finishing pigs on pasture to 50 per cent of a full feed from weaning to market and from $125 \mathrm{lbs}$. to market resulted in an increase in the length of time required to reach market weight and a significant decrease in the average daily gain. Values for the feed required per $100 \mathrm{lbs}$. of gain are only approximate because of some feed wastage resulting from feeding in open troughs. However, pigs restricted to 50 per cent of a full feed from weaning to market required 34 per cent less feed per $100 \mathrm{lbs}$. of gain. These results agree with those of Ellis and Zeller (1931), Robison (1931), and Smith et al. (1934).

Or the other hand, Saint-Pierre et al. (1934) observed that pigs receiving 50 per cent of a full feed required more feed per 100 lbs. of gain and required an additional 102 days to reach a market weight of 225 lbs. Since their work was conducted in dry lot the increase in feed required is not as inconsistent with the results observed in this work as it first appears.

Effect of Reducing the T.D.N. in the Ration on the Rate and Efficiency of Gain. In Trial II reducing the T.D.N. intake of growingfinishing pigs by the addition of fiber in the form of ground alfalfa resulted in a significant decrease in the average daily gain with an 


\section{TABLE 4}

\section{Average Within Lot Correlations of Average Back Fat Thickness as Measured by the Lean Meter and Probe and on the Carcass at a Slaughter Weight of 200 Pounds}

\begin{tabular}{|c|c|c|c|c|c|}
\hline \multirow[t]{2}{*}{ Live weight (pounds) } & 125 & 165 & 200 & \multicolumn{2}{|c|}{$\begin{array}{c}\text { Carcass } \\
\text { Measurement } \\
\text { vs. }\end{array}$} \\
\hline & \multicolumn{3}{|c|}{ Lean Meter vs. Probe } & $\begin{array}{l}\text { Lean } \\
\text { Meter }\end{array}$ & Probe \\
\hline Trial I & .090 & $.741^{* *}$ & .254 & $.538 * *$ & $.676^{* *}$ \\
\hline Trial II & $.434^{*}$ & .205 & $.722 * *$ & $.599 * *$ & $.667^{* *}$ \\
\hline
\end{tabular}

* Significant ( $\mathrm{P}$ less than 0.05 )

* Highly Significant (P less than 0.01)

increase of 12 to 32 days in the length of time required to reach a market weight of $200 \mathrm{lbs}$. Any evaluation of feed required to produce a unit of gain would not be accurate in this experiment. The pigs receiving highfiber ration No. 140 wasted a considerable amount of feed by rooting out the alfalfa meal and picking out the corn. This was then prevented by grinding the corn finely so that the physical nature of the ration ingredients was more homogeneous. Although the feed consumption figures presented in this bulletin are only approximate, the results show that reducing the T.D.N. from 75 to 58 per cent by the addition of ground alfalfa brought about an increase in the pounds of feed required to produce a unit of gain. This is consistent with the results obtained by Vestal (1921), Merkel et al. (1953), Bohman et al. (1953) and Crampton et al. (1954).

Determination of Back Fat Thickness with the Lean Meter and Probe Technique. The average within lot correlations show highly significant values between the two methods used at the 165 -lb. weight in Trial I and at the 125-and 200-lb. weights in Trial II (Table 4). No significant correlations were obtained at the other weights.

There was a highly significant correlation between the carcass back fat thickness at $200 \mathrm{lbs}$. and the back fat thickness of the live hog when taken by either of the two methods. The measurements taken with the probe were more closely related to carcass back fat thickness than were those obtained with the lean meter. The correlations obtained for the probe were +0.68 and +0.67 in Trials I and II, respectively. Correlations of +0.54 and +0.60 were obtained for the lean meter in Trials I and II, respectively.

Carcass Studies. Statistical analysis of the Trial I carcass data revealed that the average carcass length, per cent lean cuts, per cent ham 


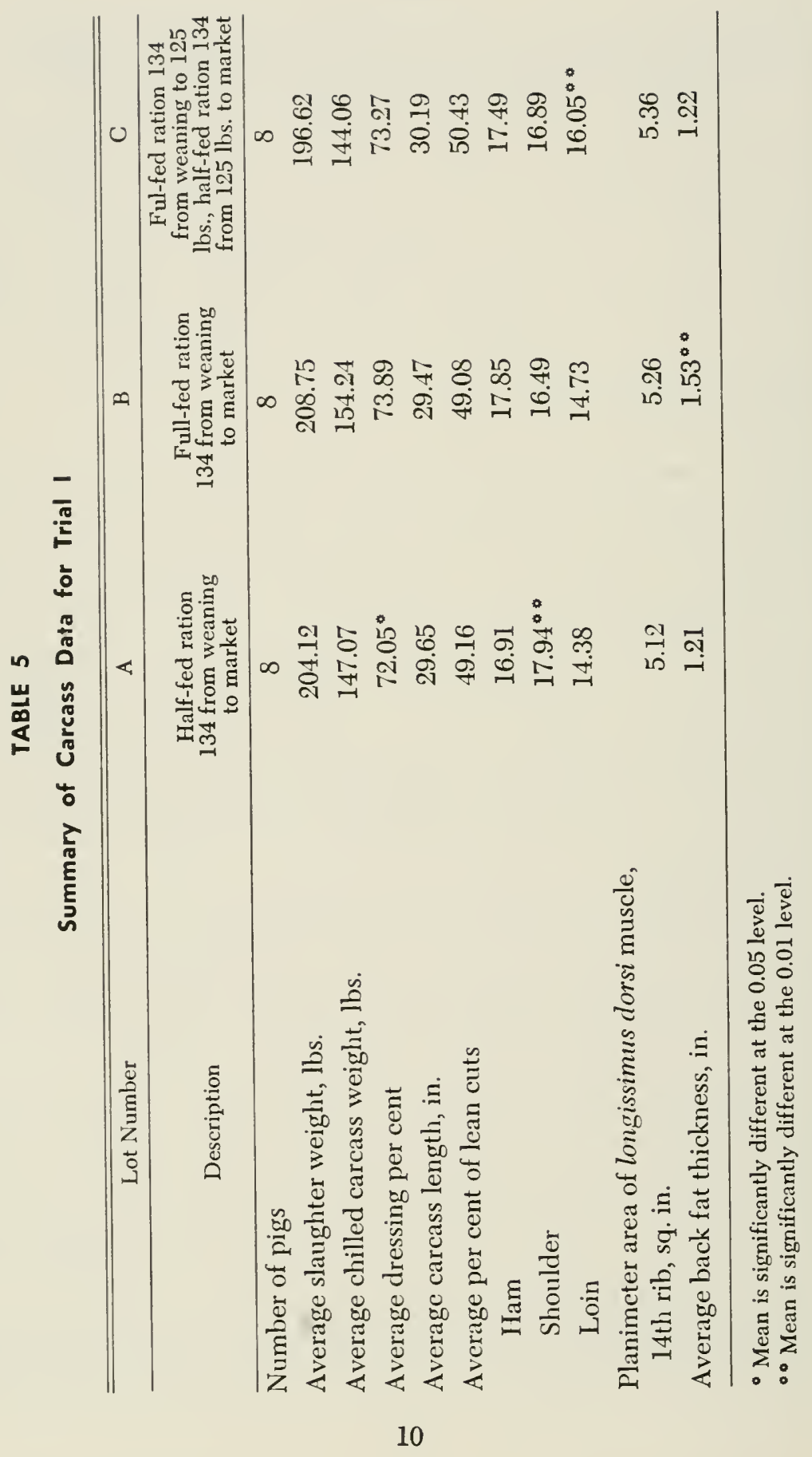


and area of longissimus dorsi muscle at the fourteenth rib were not significantly influenced by restricting the pigs to 50 per cent of a full feed (Table 5). On the other hand, a significant treatment difference in the average dressing per cent, average per cent of shoulder, average per cent of loin and average back fat thickness was evident. Since back fat thickness, which is a measure of carcass fatness, was reduced, the decrease in dressing percentage, which is markedly influenced by the amount of body fat, was not unexpected.

There was a significant breed difference in average per cent of ham and average per cent of loin. There was also a significant breed $X$ treatment interaction for per cent lean cuts, ham, and loin. Although a significant difference due to sex was noted in the average per cent of lean cuts and average per cent of loin, no sex $X$ treatment or sex $X$ breed interaction was evident.

Pigs receiving 50 per cent of a full feed from weaning to market dressed out 1.84 per cent lower than the full-fed lots, and restricting the ration from $125 \mathrm{lbs}$. to market resulted in a reduction of 0.62 in the dressing percentage, but neither reduction was significant.

A summary of carcass data for Trial II is shown in Table 6 . Restricting the T.D.N. of the ration from weaning to market or from 125 lbs. to market resulted in a significant difference in all carcass characteristics studied. A reduction in the T.D.N. of the ration from 75 per cent to 58 per cent during the entire feeding period resulted in a 3.25 per cent decrease in the average dressing per cent. This restriction resulted in an increase of 0.57 inch in the average carcass length and a 0.80 per cent increase in lean cuts. This increase in per cent lean cuts was due largely to a 0.68 per cent increase in the shoulder. A reduction of 0.14 per cent in the average per cent of loin and a reduction of 0.28 square inches in the area of the longissimus dorsi muscle is consistent with the reduction in the average per cent of loin and longissimus dorsi area obtained in the lots restricted to 50 per cent of a full feed in Trial I. Likewise, as in Trial I, the pigs on a restricted T.D.N. intake from 125 lbs. to market showed superior carcass characteristics over the other treatments. Although the pigs on a restricted T.D.N. intake from $125 \mathrm{lbs}$. to market dressed out 1.90 per cent lower than the control lot, the body length was greater by 0.60 in. A significant increase of 1.30 per cent of lean cuts may be attributed to a significant increase in the per cent of ham and shoulder, and a slight increase in the per cent of loin.

While feeding a restricted T.D.N. ration from weaning to market did not result in a reduction of the average back fat thickness, a finding 


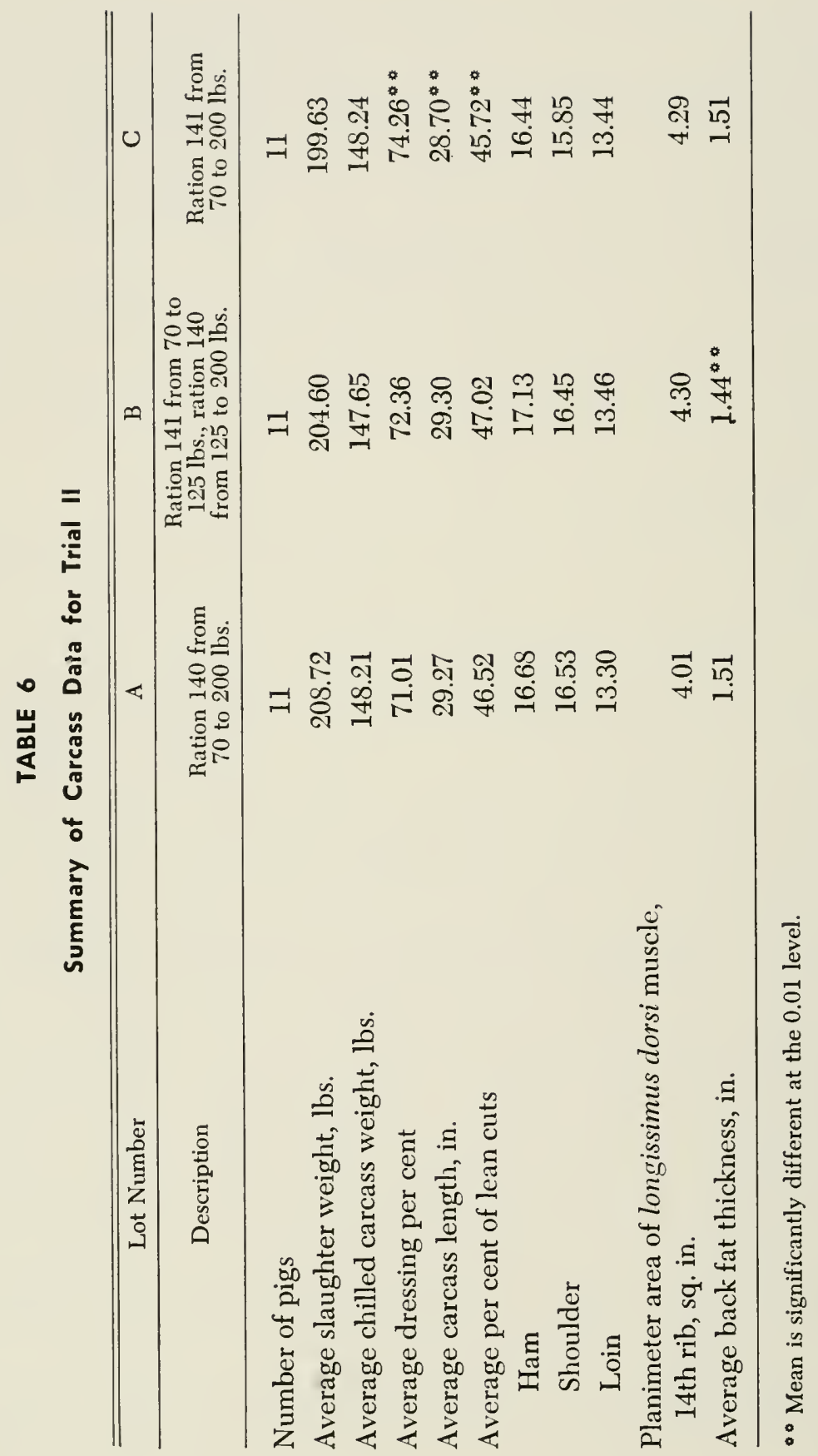


inconsistent with the reports of other workers (Robison [1928], Merkel et al. [1953], Crampton et al. [1954], and Coey and Robinson [1955]), the pigs receiving a restricted T.D.N. ration from 125 lbs. to market showed a significant decrease in the average back fat thickness. This inconsistency might be explained by sex differences and sex $X$ treatment interaction overshadowing the treatment.

The average dressing per cent for all pigs on a reduced T.D.N. intake was lower than that observed for control animals. This reduction in dressing per cent may be attributed to an increase in the weight of offal resulting from the consumption of high-fiber feeds as reported by Coey and Robinson (1955) and Bohman et al. (1955).

There was a striking similarity between the results obtained when pigs were restricted to 50 per cent of a full feed from $125 \mathrm{lbs}$. to market weight and when the T.D.N. intake was limited with a 24 per cent crude fiber ration during the same period.

A summary of the body length of live animals at market weight compared to length of carcass is shown in Table 7 .

Determination of Body Fat by the Antipyrine Technique. This work was inconclusive as the results obtained failed to give values which are consistent with information concerning the normal percentage of body fat expected of pigs in the live weight range of 125 to $200 \mathrm{lbs}$. The average body fat estimated at the three weights for animals in Trials I and II by the antipyrine method was 51.33 per cent with a range from 12.87 to 81.58 per cent within a weight range of 110 to $240 \mathrm{lbs}$. In no case did this technique permit an estimation of treatment effect upon carcass composition.

In most cases the results on any given treatment in this experiment were well above the average value of 38.4 per cent based on the physical analysis of the carcasses of 24 pigs ranging in weight from 64 to $340 \mathrm{lbs}$. or the value of 36.7 per cent obtained with the antipyrine method applied to the same animals (Kraybill et al. 1953). It is possible that contrasting results are due in part to slight differences in experimental procedure and to the estimation of the antipyrine in the blood plasma. Kraybill et al. (1953) injected the drug via the anterior vena cava or a prominent ear vein, and obtained blood samples from either the tail or an ear vein, and in a few cases the anterior vena cava. An attempt to quantitatively inject antipyrine into the ear vein was unsuccessful in this work, partially due to the effect of ear notching on the development of veins in the ear. Fletcher (1956) stated "one of the most difficult parts of this method is quantitative injection and satisfactory sampling. The results obtained could result if an abnormal antipyrine concentration persisted in the vena cava where injection and sampling took place. This conceivably 


\section{TABLE 7}

\section{Summary of Body Length of Live Animals at Market Weight Compared to Length of Carcass \\ Trials I and II}

\begin{tabular}{|c|c|c|c|c|}
\hline Treatment & $\begin{array}{l}\text { No. of } \\
\text { pigs }\end{array}$ & $\begin{array}{l}\text { Average body } \\
\text { length of live } \\
\text { animals (in.) }\end{array}$ & $\begin{array}{c}\text { Average } \\
\text { length of } \\
\text { carcass (in.) }\end{array}$ & $\begin{array}{l}\text { Correlation } \\
\text { coefficient }\end{array}$ \\
\hline $\begin{array}{l}\text { Half-fed ration } 134 \text { from } \\
\text { weaning to market }\end{array}$ & 10 & 42.20 & 29.77 & \\
\hline $\begin{array}{l}\text { Full-fed ration } 134 \text { from } \\
\text { weaning to } 125 \text { lbs., half- }\end{array}$ & & & & \\
\hline $\begin{array}{l}\text { fed from } 125 \text { lbs. to market } \\
\text { Full-fed ration } 134 \text { from }\end{array}$ & t 10 & 42.35 & 30.09 & \\
\hline weaning to market & 8 & 42.89 & 29.39 & \\
\hline Average for Trial I & $\ldots$ & 42.48 & 29.75 & $.591^{\circ \circ}$ \\
\hline $\begin{array}{l}\text { High fiber ration } 140 \text { from } \\
\text { weaning to market }\end{array}$ & 11 & 41.99 & 29.27 & \\
\hline $\begin{array}{l}\text { Low fiber ration } 141 \text { from } \\
\text { weaning to } 125 \text { lbs., high } \\
\text { fiber ration } 140 \text { from } 125\end{array}$ & & & & \\
\hline lbs. to market & 11 & 41.98 & 29.30 & \\
\hline $\begin{array}{l}\text { Low fiber ration } 141 \text { from } \\
\text { weaning to market }\end{array}$ & 11 & 41.04 & 28.69 & \\
\hline Average for Trial II & & 41.67 & 29.08 & .290 \\
\hline
\end{tabular}

${ }^{\circ}$ Highly Significant (P less than 0.01 )

could occur, if during injection, considerable drug escaped into the tissue in the area of the vena cava and later continued to be a source of elevated local concentration." Under the conditions of this experiment it is possible that an elevated concentration of the drug existed in the area of the vena cava, although the injection of the drug was done slowly and with care. In no case was there any reason to suspect that all of the solution injected did not enter the circulatory system.

The possibility of an abnormal concentration of the drug in the area of injection certainly warrants further consideration. If the drug is injected via the anterior vena cava, taking subsequent blood samples from other sites such as the tail or ear vein would remove the possibility of obtaining samples with an elevated concentration.

Soberman et al. (1949) found that antipyrine is bound by plasma protein to the extent of about 10 per cent. This factor and the rate of metabolism could markedly influence the accuracy of the antipyrine 
technique as a means of measuring body fat in swine. Since the rate of metabolism of antipyrine is a function of time, it would seem that the accuracy of this technique could be considerably improved by sampling more frequently and sooner after injection.

Fasting of the pigs 12-18 hours prior to injection of the drug, as is done with cattle (Kraybill et al., 1950), seems worth exploring. Since this method is based on the degree of dilution of the drug in the total body water following intravenous injection, it is conceivable that any liquids consumed just prior to the injection of the drug would result in an abnormal degree of dilution.

\section{Summary}

Sixty purebred Berkshire and Duroc pigs were fed at different nutrient levels during the experimental periods.

In Trial I the experimental pigs were maintained on bluegrass-white clover pasture plots and hand-fed a fortified corn-soybean oil meal ration. When the feed intake was restricted to 50 per cent of a full feed from weaning to $200 \mathrm{lbs}$. or from 125 to $200 \mathrm{lbs}$., a highly significant decrease in average daily gain and a decrease in amount of feed required to produce a unit of gain was observed. The average carcass length, per cent lean cuts, per cent ham and area of longissimus dorsi muscle were not significantly influenced by restricted feeding. However, a significant treatment difference in favor of restricted feeding was observed in the average per cent of shoulder, per cent of loin, and back fat thickness. The dressing percentage of the restricted-fed pigs was consistently lower than that of the full-fed animals. In all cases, the pigs on a full feed from weaning to $125 \mathrm{lbs}$. live weight, and thereafter fed 50 per cent of a full feed, produced carcasses superior in leanness as reflected in a larger per cent of lean cuts and area of the longissimus dorsi muscle.

In Trial II pigs fed a corn-soybean oil meal ration diluted with ground alfalfa to reduce the T.D.N. of the ration from 75 to 58 per cent showed a significant decrease in the rate of gain and an increase in the feed required to produce a unit of gain. The carcasses of pigs receiving the high fiber ration from weaning to $200 \mathrm{lbs}$. or from 125 to $200 \mathrm{lbs}$. showed a significant superiority in all the carcass characteristics studied.

A comparative evaluation of the lean meter and probe technique for measuring the back fat thickness of live hogs showed highly significant correlations between the two methods. Highly significant correlations were also obtained between the average back fat thickness of the carcass and measurements taken by either of the two instruments at 
200 lbs. live weight. The measurements taken with the probe showed a higher correlation to average back fat thickness of the carcass than did the lean meter.

The use of the antipyrine technique to determine the per cent body fat of swine was unsuccessful. The body fat values obtained were well above the normal percentage of body fat expected of pigs in this weight range. 


\section{BIBLIOGRAPHY}

Bohman, V. R., J. Kidwell and J. McCormick. 1953. High levels of alfalfa in the ration of growing-fattening swine. J. of Animal Sci., 12: 886.

Bohman, V. R., J. Hunter and J. McCormick. 1955. The effect of graded levels of alfalfa and aureomycin upon growing-fattening swine. J. of Animal Sci., 14: 499.

Brodie, B. B., J. Axelrod, R. Soberman and B. Levy. 1949. The estimation of antipyrine in biological materials. J. of Biological Chem., 179: 25-29.

Coey, W. E. and K. L. Robinson. 1955. Some effects of dietary crude fiber on live weight gains and carcass conformation of pigs. J. of Agr. Sci., 45: 41-47.

Crampton, E. W., G. Ashton and L. Lloyd. 1954. The effect of restricting feed intake of market hogs during the finishing period on the quality of the bacon carcass. J. of Animal Sci., 13: 321-326.

Crampton, E. W., G. Ashton and L. Lloyd. 1954. Improvement of bacon carcass quality by the introduction of fibrous feeds into the hog finishing ration. J. of Animal Sci., 13: 327.

Ellis, N. R. and J. H. Zeller. 1931. Utilization of feed by swine as affected by level of intake. Proc. Amer. Soc. Animal Prod., January, 1932, 270-274.

Fletcher, J. L. 1956. Personal correspondence. Geneticist, Meat Production and Quality, Research Section, U.S.D.A., Beltsville, Maryland.

Hazel, L. N. and E. A. Kline. 1952. Mechanical measurement of fatness and carcass value on live hogs. J. of Animal Sci., 11: 313.

Kraybill, H. F., O. B Hankins and H. L. Bitter. 1950. Estimation of body fat from measurement in vivo of body water by use of antipyrine. J. of App. Physiology, 3: 681 .

Kraybill, H. F., E. R. Goode, R. S. Robertson and H. S. Sloane. 1953. In vivo measurement of body fat and body water in swine. J. of App. Physiology, 6: 27-32.

McMeekan, C. P. 1940. Growth and development in the pig, with special reference to carcass quality characters. J. of Agr. Sci., 30: 276-343.

Merkel, R. A., R. W. Bray, R. H. Grummer, P. H. Phillips and G. Bohstedt. 1953. The influence of limited feeding, by use of high fiber rations, upon growth, fattening and carcass characteristics of swine. J. of Animal Sci., (Proc.), 12: 903.

Robison, W. L. 1928. The effects of grains, fiber, type and weight on the yield of pork cuts. Proc. Amer. Soc. Animal Prod., 21: 91-95.

Robison, W. L. 1931. Full and limited feeding of pigs on pasture. Proc. Amer. Soc. Animal Prod., January, 1932, 286-289.

Saint-Pierre, J. M., F. B. Morrison and J. P. Willman. 1934. Relative efficiency of limited and full-feeding for fattening pigs in dry lot. Proc. Amer. Soc. Animal Prod., 27: 101-104.

Smith, H. J., J. Cole, C. Hobbs, J. Ewing, E. Chapman and J. McLaren. 1950. The effect of pasture on rate and efficiency of gain and on carcasses of swine full-fed and fed eighty and sixty per cent of a full-feed. J. of Animal Sci., (Proc.), 9: 676.

Snedecor, G. W. 1946. Statistical methods. Ames, Iowa: Iowa State College Press.

Soberman, R., B. B. Brodie, B. B. Levy, J. Axelrod, V. Hollander and J. M. Steele. 1949. The use of antipyrine in the measurement of total body water in man. J. of Biol. Chem., 179: 31 .

Vestal, C. M. 1921. Fiber in rations for fattening swine. Proc. Amer. Soc. Animal Prod., 14: 43.

Zinn, D. W. 1956. The effect of restricting the nutrient allowance on the carcass composition of swine. M. S. Thesis, West Virginia University. 


bing

10.0 .

golos

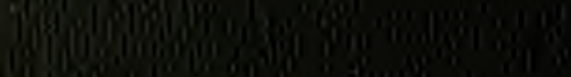

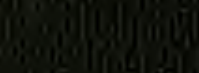

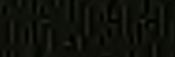

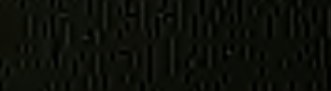

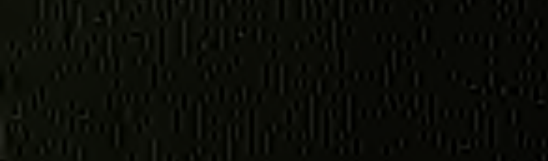

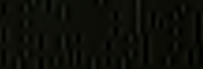

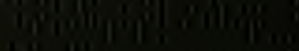

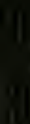

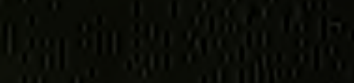

ang

14

(1)

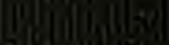

if

at: 